\title{
The Effect of Project-Based Learning on Students' Attitude Towards English Classes
}

\author{
Burcu Duman ${ }^{1}$, Özlem Kuuk Yavuz ${ }^{2}$ \\ ${ }^{1}$ Bartin University, Faculty of Education, Turkey \\ ${ }^{2}$ KDZ Ereğli İMKB Atatürk Anatolian High School, Zonguldak, Turkey \\ Correspondence: Burcu Duman, Bartin University, Faculty of Education, Turkey.
}

Received: November 11, 2018

doi:10.11114/jets.v6i11a.3816

\author{
Accepted: November 22, $2018 \quad$ Online Published: November 29, 2018 \\ URL: https://doi.org/10.11114/jets.v6i11a.3816
}

\begin{abstract}
The purpose of this research is to define the effect of project- based learning on students' attitude towards English classes. The study group of the research consisted of 51 students attending grade 10 at an Anatolian high school in the Western Black Sea region of Turkey. In the quantitatively designed research, the "control group pre-test- post-test design", one of the experimental designs, was applied. The "Scale of Attitude towards English Classes" was used as the data collection tool. The scale consists of 20 items and three sub-dimensions. The research data were compared by applying the Mann Whitney U test and the Wilcoxon Signed-Rank Test, calculating the standard deviation value and arithmetic average on the SPSS22 program. Results of the research indicate that there was a significant difference between the experimental group's pre-test and post-test scores in favour of the post-test. There was a significant difference between the experimental and control groups' post-test results in favour of the experimental group.
\end{abstract}

Keywords: project-based learning, English course, attitude

\section{Introduction}

In the current education system in which learning how to learn is acknowledged, conveying the internalized knowledge into life by restructuring it is only possible through an environment serving to improve the high- order cognitive skills (Demirel, 2013, 20). In this respect, project-based learning (PBL) is one of the most effective ways to make students realize the problems around them by taking up a more active role in the learning environment, to make them find out different solutions to those problems and to maintain the learning process (Gomleksiz\&Fidan, 2013, 120). PBL is defined as "a systematic learning method which aims at improving students' knowledge and skills through a long-term learning process involving the product and activities designed in a detailed way through authentic questions and issues" (English \&Kitsantas, 2013, 130). Project-based learning can be described as a student-centered education which takes a long timespan in which students pick, plan, research and produce a product, presentation or performance answering a question or a problem to be encountered in actual life. (Holm, 2011, 1).

The word "project" in "project- based learning" emphasizes the idea or the development of an idea, imagination and planning (Erdem\&Akkoyunlu, 2002, 2). Therefore, the project does not imply a completed version but the edit or editing (Erdem, 2002, 178). The project is actually the prevision of a task to be done (Erdem\&Akkoyunlu, 2002, 2). As a result, PBL is teaching based on improving an idea, imagination, planning and editing. Contemplation and editing require one not to gravitate towards the end product, but towards the process itself before anything else, because ideas and edits are thinking structures that are open to changes. The word "based", one of the main words constructing the approach, puts emphasis on the idea that the project is not a component of a goal but a component of infrastructure and indicates a process-oriented structure. The word "learning", on the other hand, is significant in the sense that it attracts the attention not to the instructor but to the learner (Erdem, 2002, 173). The project-based learning approach is a learning approach aiming at the solution of problems via the individual or small groups with an attitude resembling life under natural circumstances (Korkmaz \&Kaptan, 2001, 193).

PBL is a process in which students' knowledge and skills support lifelong learning, encouraging autonomous learning. This process consists of the following steps: 1. Defining the topic and subtopics and organizing the groups in themselves; 2. Groups creating their project environment; 3. Applying the project; 4. Planning the presentation; 5. Presentation; 6. Evaluation (Korkmaz \&Kaptan, 2001, 194, 196). In the PBL approach, the main purpose is to make the 
students acquire the exploration skill and discover their own learning type and method (Yurttepe, 2007, 11). The teacher is a guide, strategically instructing the students throughout the activities and making it easy for them to carry out the activities (Holm, 2011,1). The teacher has a mission of creating proper activities for the individuals, as well as creating an environment in which students will be able to comfortably express their opinions and find solutions to the problems they encounter (Applefield, Huber \&Moallem, 2001, 239).

In PBL, individuals who work cooperatively actively take part in activities by taking over individual responsibilities after the determination of the questions which are decided on in line with the educational attainments and the products to constitute the sense of responsibility. As a result, PBL contributes to the development of the sense of responsibility in students while also allowing them to give shape to their own learning; thereby making the learning process more interesting and meaningful. The more chance the students are given to determine their own learning purpose, the more interested they become in the learning process. (Rasul and Hassan, 2011, 325). PBL can be claimed to make a person capable of solving problems, thinking analytically and critically, doing research, making decisions, taking responsibility and working cooperatively in a technology-based learning environment, within limited durations of time (Erdem, 2002, 178). When the characteristics of this approach are taken into account, PBL is considered to be effective in the development of language skills. As interaction and communication are the main factors in language acquisition, a learning environment should be organized to maximize the interaction between students as well as their problem-solving skills regarding reality (Mc Carthy, 2010, 226). Therefore, project-based learning is acknowledged as a significant way of encouraging the simultaneous acquisition of the language, content and skills by means of projects (Hedge, 1993). Students having the chance to reach authentic materials with the help of technology have the advantage of contacting different people from whom they will receive information by communicating in the target language while working on the project. Also, they will encounter speech patterns which otherwise they would not have been exposed to in the same process. In other words, students make a meaningful connection between the language and the use of it thanks to the projects (Legutke\& Thomas 1991, 214).

It is observed that many research-studies have analysed the effect of PBL on academic success, (Dilseker, 2008; Karacalli, 2011), motivation (Koparan\&Guven, 2014; Aydın, Demir Atalay\&Goksu, 2017), high-order cognitive skills (Tonbuloglu et al., 2013), creativity (Yilmaz, 2006) and attitude (Erdem\&Akkoyunlu, 2002; Yilmaz, 2006; Dilseker, 2008; Cibik, 2009; Karacallı, 2011; Comert, 2014; Koparan\&Guven, 2014; Ayaz \&Soylemez, 2015), in mostly science and technology classes alongside biology, geometry classes, etc. However, research analysing its effects on teaching English as a foreign language is quite limited (Cirak, 2006; Bas \&Beyhan, 2010; Bas, 2011; Koroglu, 2011; Yaman, 2014; Yiying, 2015; Avsar, 2017). While these limited research studies mostly focus on academic success, the research on attitude is relatively less common (Baş\&Beyhan, 2010; Baş, 2011). However, attitude, which is one of the individual character traits that students have, is thought to have either a direct or an indirect effect on the acquisition of a foreign language (Kirkiz, 2010, 20). Knowledge, belief and emotions are in a systematic and continual organizational interaction in the formation of attitude. This situation indicates that the presence of the learning process is important in the formation of attitude. The learning process also indicates the mutability of attitude (Inceoglu, 2011, 29). Based on this, we can say that the learning approach applied during the learning process is effective in changing attitude. Thus, the impact of the PBL approach on the learning process and on the students' attitude towards English classes is to be analysed.

\section{Method}

The "Control group pre-test - post-test design", one of the "experimental designs," was applied to this quantitatively designed research. This pattern is used in conditions where pre-experiment and post-experiment evaluations constructed with a random method are made in the experimental and control groups (Karasar, 2006, 97). Based on this pattern, answers to the following questions were sought:

- Is there a significant difference between the pre-test attitude scores of the experimental and control group?

- Is there a significant difference between the post-test attitude scores of the experimental and control group?

- Is there a significant difference between the pre-test and post-test attitude scores of the control group?

- Is there a significant difference between the pre-test and post-test attitude scores of the experimental group?

\section{Study Group}

The study group of the research consisted of 51 grade 10 students attending an Anatolian high school in a province located in the Western Black Sea region of Turkey in the 2017-2018 academic year. Cluster analysis was applied to balance the experimental and control groups. In the cluster analysis, students' English grade averages of the previous year and the answers they gave to the "Scale for Attitude towards English Classes" were taken into consideration (Kirkiz, 2010). As a result of the cluster analysis, 51 students were chosen for the study group. The distribution of the 
51 students in classes was analysed. In the end, class 10/A was decided to be the control group while class 10/D was decided to be the experimental group. 27 of the students took part in the experimental group while 24 of them took part in the control group.

\section{Experiment}

The research was applied during the English classes. Educational attainments of the grade 10 curriculum subjects "Quantifiers" and "Modals" were focused on. Classes were carried out in line with the project-based learning approach in the experimental group while in the control group classes were carried out as the current curriculum requires. The experiment went on for six weeks.

In the first week, "the Scale for Attitude towards English Classes" was applied as pre-test to both the experimental and control groups. A significant difference between the pre-test attitude results of the experimental and control groups was not observed (Mann-Whitney $\mathrm{U}=263,00 ; \mathrm{p}=.25$ ). This result shows that prior to the experiment, the attitudes of the experimental and control groups towards English classes had been equal (Table 1).

At the beginning, the experimental group was informed about what the project-based learning approach is, its content, stages, how the application process was going to be carried out, what the groups should be careful about while working on the project, and which technological devices they could use to create authentic works. With the participation of the students, the subject of the project was decided to be "the Design of Life in the 3000s Considering the Speed of Developments in Technology". The experimental group was divided into five project groups consisting of 5 or 6 students. In the light of the project subject, five subtopics were determined as follows: "Education System in the3000s", "Health Services in the 3000s", "Economy in the 3000s", "Smart Houses in the 3000s", "Means of Transportation in the 3000s". These were distributed by drawing lots. The whole class brainstormed on the topics, and students penned their opinions regarding their expectations and views on the project. Groups agreed on names to represent them and shared the tasks among the members.

In the second week, students researched websites and resources to be used besides sharing authentic materials and videos regarding the technological developments on the subject. Groups prepared their own working schedule and decided on the methods and materials they would need in the process. In weeks three and four, group members exchanged ideas in line with their division of labour, and started the application process upon forming their projects. The researcher taught the students the grammatical forms regarding the subject in order to realize the educational attainments. Groups translated the products of the project into English for presentation. The researcher supported the students whenever they needed it while other groups helped one another as well. In week five, upon being planned, presentations were done. Self-assessment and peer assessment along with rubrics were used in the evaluation of the project process and products. In the last week, the "Scale for Attitude towards English Classes" was applied to the experimental and control groups as the post-test.

\section{Data Collection Tool}

The "Scale for Attitude towards English Classes" adjusted to English classes by Kirkiz (2010) from the "Scale for Attitude towards Geography Classes" developed by Guven\&Uzman (2006) was used as the data collection tool. The scale has five Likert-type ratings as follows: "Completely Agree", "Agree", "'Neutral", "Disagree", "Completely Disagree". The scale consists of 20 articles (10 positive and 10 negative) and three subdimensions. The first subdimension reflects the attitude towards the general characteristics of the English classes. The second subdimension reflects the attitude towards the ability of the subjects of the English classes to attract attention while the third dimension reflects the attitude towards the teaching style of the English teacher. Factor loads of the 20 articles vary between 0.34 and 0.71 . The Cronbach's alpha internal consistency of the whole scale is calculated to be $0 ., 93$.

\section{Data Analysis}

SPSS 22 was used in the analysis of data. Mann-Whitney U (MWU) test was used while comparing the experimental and control groups' average of pre-test scores to the experimental and control groups' average of post- test scores. Wilcoxon signed-ranks test was used while comparing the experimental and control groups' average of pre-test scores to the experimental and control groups' average of post- test scores. Significance level was acknowledged to be .05 in the data analysis.

\section{Findings}

The findings of the research are presented respective of the questions of the research. Table 1 displays the findings regarding the averages of the pre-test attitude scores of the experimental and control group. 
Table 1. Findings Regarding the Averages of the Pre-test Attitude Scores of the Experiment and Control Group

\begin{tabular}{|c|c|c|c|c|c|c|}
\hline Subdimensions & Groups (pretest) & $\mathbf{n}$ & Mean Rank. & Total Rank & MWU & $\mathbf{p}$ \\
\hline \multirow{2}{*}{ Characteristics and significance of the Class } & Experiment & 27 & 28,69 & 774,50 & \multirow{2}{*}{251,500} & \multirow{2}{*}{.17} \\
\hline & Control & 24 & 22,98 & 551,50 & & \\
\hline \multirow{2}{*}{ Appeal of the subject } & Experiment & 27 & 27,31 & 737,50 & \multirow{2}{*}{288,500} & \multirow{2}{*}{.50} \\
\hline & Control & 24 & 24,52 & 588,50 & & \\
\hline \multirow{2}{*}{ Teaching Style of the English Teacher } & Experiment & 27 & 28,76 & 776,50 & \multirow{2}{*}{249,500} & \multirow{2}{*}{.15} \\
\hline & Control & 24 & 22,90 & 549,50 & & \\
\hline \multirow{2}{*}{ General } & Experiment & 27 & 28,26 & 763,00 & \multirow{2}{*}{263,000} & \multirow{2}{*}{.25} \\
\hline & Control & 24 & 23,46 & 563,00 & & \\
\hline
\end{tabular}

There is not a significant difference between the experimental and control groups of all the sub-dimensions or the scale in general when the pre-test attitude scores of the experimental and control groups are analysed in Table 1. This proves that the attitudes of the experimental and control group toward English classes prior to the experiment had been equal. In other words, it shows that there is not a significant difference between the attitudes of the experimental and the control group. Table 2 displays the findings regarding the post- test attitude scores of the experimental and the control group.

Table 2. Findings Regarding the Averages of the Post Test Attitude Scores of the Experiment and Control Group

\begin{tabular}{|c|c|c|c|c|c|c|}
\hline Subdimensions & Groups (post test) & $\mathbf{n}$ & Mean Rank & Total Rank & MWU & $\mathbf{p}$ \\
\hline \multirow{2}{*}{ Characteristics and significance of the Class } & Experiment & 27 & 30,00 & 810,00 & \multirow{2}{*}{$216,000^{*}$} & \multirow{2}{*}{.04} \\
\hline & Control & 24 & 21,50 & 516,00 & & \\
\hline \multirow{2}{*}{ Appeal of the subject } & Experiment & 27 & 27,04 & 730,00 & \multirow{2}{*}{296,000} & \multirow{2}{*}{.60} \\
\hline & Control & 24 & 24,83 & 596,00 & & \\
\hline \multirow{2}{*}{ Teaching Style of the English Teacher } & Experiment & 27 & 34,04 & 919,00 & \multirow{2}{*}{$107,000 *$} & \multirow{2}{*}{.00} \\
\hline & Control & 24 & 16,96 & 407,00 & & \\
\hline \multirow{2}{*}{ General } & Experiment & 27 & 30,37 & 820,00 & \multirow{2}{*}{$206,000 *$} & \multirow{2}{*}{.03} \\
\hline & Control & 24 & 21,08 & 506,00 & & \\
\hline
\end{tabular}

When Table 2 is analysed, it can be observed that there is a significant difference between the post-test attitude scores of the experimental and control groups in favour of the experimental group in all subdimensions and the scale in general except for the appeal of the subject dimension. (Characteristics and significance of the class: MWU=216.000; Appeal of the subject: MWU=296.000; Teaching Style of the English Teacher: MWU=107.000, Scale in general: MWU=206.000) $(\mathrm{p}<0.05)$. These findings show that in comparison with the current curriculum, the project-based learning approach positively affects the students' attitude towards the characteristics and significance of the English class as well as the teacher's teaching style, and the attitude toward English classes in general. In other words, when compared to the current curriculum, the PBL approach is more effective in improving students' attitude towards English classes. Table 3 displays the findings regarding the pre-test and post- test attitude scores of the control group.

Table 3. Findings Regarding the Pre-test and Post- Test Attitude Scores of the Control Group

\begin{tabular}{|c|c|c|c|c|c|c|c|}
\hline Subdimensions & Tests & Control Group & $\mathbf{n}$ & Mean Rank & Total Rank & Wilcoxon (z) & $\mathbf{P}$ \\
\hline Characteristics and significance of the Class & $\begin{array}{c}\text { Post test } \\
\text { Pretest }\end{array}$ & $\begin{array}{c}\text { Negative Rank } \\
\text { Positive Rank } \\
\text { Equal }\end{array}$ & $\begin{array}{c}11 \\
11 \\
2 \\
\end{array}$ & $\begin{array}{l}12,50 \\
10,50\end{array}$ & $\begin{array}{l}137,50 \\
115,50\end{array}$ & $-0,357$ & .72 \\
\hline Appeal of the subject & $\begin{array}{c}\text { Post test } \\
\text { Pretest }\end{array}$ & $\begin{array}{c}\text { Negative Rank } \\
\text { Positive Rank } \\
\text { Equal } \\
\end{array}$ & $\begin{array}{c}10 \\
13 \\
1 \\
\end{array}$ & $\begin{array}{l}12,50 \\
11,62\end{array}$ & $\begin{array}{l}125,00 \\
151,00\end{array}$ & $-0,397$ & .69 \\
\hline Teaching Style of the English Teacher & $\begin{array}{c}\text { Post test } \\
\text { Pretest }\end{array}$ & $\begin{array}{c}\text { Negative Rank } \\
\text { Positive Rank } \\
\text { Equal } \\
\end{array}$ & $\begin{array}{c}16 \\
6 \\
2 \\
\end{array}$ & $\begin{array}{l}11,34 \\
11,92\end{array}$ & $\begin{array}{c}181,50 \\
71,50\end{array}$ & $-1,795$ & .07 \\
\hline General & $\begin{array}{c}\text { Post test } \\
\text { Pretest }\end{array}$ & $\begin{array}{c}\text { Negative Rank } \\
\text { Positive Rank } \\
\text { Equal }\end{array}$ & $\begin{array}{c}11 \\
12 \\
1\end{array}$ & $\begin{array}{l}13,50 \\
10,63\end{array}$ & $\begin{array}{l}148,50 \\
127,50\end{array}$ & $-0,320$ & .74 \\
\hline
\end{tabular}

According to Table 3, there is not a significant difference between the pre-test and post- test attitude scores of the control group in all sub-dimensions or the scale in general. This proves that the current curriculum does not improve the students' attitude towards English classes. Table 4 displays the findings regarding the pre-test-post- test attitude scores of the experimental group. 
Table 4. Findings Regarding the Pre-test and Post-Test Attitude Scores of the Experimental Group

\begin{tabular}{|c|c|c|c|c|c|c|c|}
\hline Subdimensions & Tests & $\begin{array}{l}\text { Experiment } \\
\text { Group }\end{array}$ & $\mathbf{n}$ & $\begin{array}{l}\text { Mean } \\
\text { Rank }\end{array}$ & $\begin{array}{l}\text { Total } \\
\text { Rank }\end{array}$ & $\begin{array}{l}\text { Wilcoxon } \\
\quad(z)\end{array}$ & $\mathbf{p}$ \\
\hline $\begin{array}{c}\text { Characteristics and significance of } \\
\text { the Class }\end{array}$ & $\begin{array}{l}\text { Post test } \\
\text { Pretest }\end{array}$ & $\begin{array}{c}\text { NegativeRank } \\
\text { Positive Rank } \\
\text { Equal }\end{array}$ & $\begin{array}{c}9 \\
15 \\
3\end{array}$ & $\begin{array}{l}11,83 \\
12,90\end{array}$ & $\begin{array}{l}106,50 \\
193,50\end{array}$ & $-1,245$ & .21 \\
\hline Appeal of the subject & $\begin{array}{c}\text { Post test } \\
\text { Pretest }\end{array}$ & $\begin{array}{c}\text { Negative Rank } \\
\text { Positive Rank } \\
\text { Equal }\end{array}$ & $\begin{array}{c}12 \\
9 \\
6\end{array}$ & $\begin{array}{l}11,17 \\
10,78\end{array}$ & $\begin{array}{l}134,00 \\
97,00\end{array}$ &,- 648 & .52 \\
\hline Teaching Style of the English Teacher & $\begin{array}{l}\text { Post test } \\
\text { Pretest }\end{array}$ & $\begin{array}{c}\text { Negative Rank } \\
\text { Positive Rank } \\
\text { Equal }\end{array}$ & $\begin{array}{c}3 \\
12 \\
12 \\
\end{array}$ & $\begin{array}{l}5,83 \\
8,54\end{array}$ & $\begin{array}{c}17,50 \\
102,50\end{array}$ & $-2,447 *$ & .01 \\
\hline General & $\begin{array}{l}\text { Post test } \\
\text { Pretest }\end{array}$ & $\begin{array}{c}\text { Negative Rank } \\
\text { Positive Rank } \\
\text { Equal }\end{array}$ & $\begin{array}{c}12 \\
14 \\
1 \\
\end{array}$ & $\begin{array}{l}11,00 \\
15,64\end{array}$ & $\begin{array}{l}132,00 \\
219,00\end{array}$ & $-1,107$ & .27 \\
\hline
\end{tabular}

Analysing Table 4, there is a significant difference between the pre-test and post- test attitude scores of the experimental group in favour of the post- test in the teaching style of the English teacher subdimension $(\mathrm{z}=-2 ., 447 ; \mathrm{p}<0.05)$. There is not a significant difference in other sub-dimensions or the scale in general. In the light of these findings, the English teacher's application of the PBL approach positively affects the students' attitude towards the English classes. In other words, the PBL approach can be claimed to be a significant factor in developing a positive attitude toward English classes. On the other side, it can be suggested that the PBL approach does not have a significant effect on the attitude towards the characteristics and the significance of class or the appeal of the subject.

\section{Results, Conclusions and Recommendations}

Project-based learning is an approach based on the development of ideas, imagination, planning and editing. PBL emphasizes the period in which the learners, either individually or as a group, plan their own learning process, do research, and improve the skills of working cooperatively, taking responsibility, and obtaining information as well as organizing the information (Erdem\&Akkoyunlu, 2002). In this sense, it is crucial to analyse the impact of PBL on the education process and foreign language teaching. On the other hand, the attitude of students towards the language being taught is a factor which affects their learning process (Brown, 2000). Gardner and Lumbert (1972) as well as Burstall (1975) found out as a result of the research they had done on the topic of language acquisition that attitude plays a significant role in the acquisition of a foreign language. Gardner (1985) states that students with a positive attitude are academically far more successful than students with a negative attitude. Therefore, in addition to academic success, the impact of attitude -an effect on academic success- on the education process is also one of the primary topics being researched.

This project, aiming at defining the effect of the project- based learning approach on students' attitude towards English classes was carried out by applying the control group pre-test - post-test experimental design. Classes were taught in line with the project-based learning approach to the experimental group while the current curriculum was applied in the classes of the control group. As a result of the research, there was not a significant difference between the pre-tests of the experimental group and the control group to whom the current curriculum was applied. However, the post- tests applied after the experiment indicate a significant difference on behalf of the experimental group. This result implies that in comparison with the current instruction, PBL generally improves the attitude of the students towards English classes. PBL especially creates an impact on the attitudes towards the attention to class and teaching. The current curriculum, on the other hand, does not have a positive effect on students' attitude towards improving them. When the experimental group's change of attitude before and after the experiment is observed, it is seen that the teaching style of the English teacher affected them and their attitude positively.

Bas (2011)'s research, in which he analyses the effect of project-based learning on students' academic success and attitude in grade 9 English classes, indicates that PBL creates a positive and significant difference in both academic success and attitude. In Bas and Beyhan (2010)'s research, it is observed that the practice of multiple intelligence theory along with PBL in grade 5 English classes affects the students' attitude towards these classes positively, and, that the students in the experimental group practising the activities of multiple intelligence supported by PBL are more motivated. Furthermore, in the research of Ciftci (2006), Gultekin (2005), Erdem and Akkoyunlu (2002) and Ozdemir (2006), project-based learning, compared to the traditional language teaching methods, creates significant differences in the attitude towards classes. In addition, it was concluded from the studies that Bayram \&Seloni (2014) conducted with primary school students and that Coskun (2004) conducted with high school students that project-based learning 
positively affects students' attitude towards the classes. All of these results are similar to the results of this research. Nevertheless, there are also studies with different results. For instance, in Demirel and et al.'s (2000) and Yurtluk's (2003) experimental research studies, no difference was observed between the PBL applied to the experimental group and the traditional method applied to the control group when it came to improving attitude. In Baran \&Maskan's (2009) research, on the other hand, no effect of PBL on attitude was observed. From McCarthy's (2010) point of view, the project- based learning approach improves the students' autonomous learning in foreign language acquisition, boosts students' motivation for learning a language, and makes it possible for students to communicate better in a community while using the target language. Beneke\&Ostrosky (2008), and Faris (2008) proved that PBL helps increase the students' motivation. Hilton-Jones (1988) points out that PBL has not only developed students' language skills but that research and practice in authentic environments have also made them aware of future needs and increased the demand for language acquisition. When the research is considered as a whole and similar results from other research studies are taken into account, the PBL approach can be claimed to affect students in developing a positive attitude towards the class besides increasing academic success and motivation and developing high- order cognitive skills. Based on these, suggestions can be proposed as follows: the PBL approach can be used in different grades and levels to improve students' attitude towards classes. Teachers and pre-service teachers can be educated on the PBL approach in workshops and courses. In this research, the effect of PBL on secondary education level was researched. Apart from being aware of the fact that most of the research on the topic is on primary school level, the effect of PBL on other education levels can be researched. The quantitative method was applied in this research. However, using both the qualitative and quantitative methods in similar research to be carried out in the future may yield more fruitful results.

\section{References}

Applefield, J. M., Huber, R., \& Moallem, M. (2001). Constructivism in theory and practice: toward a better understanding. High School Journal, 84(2), 35-53.

Avşar, Ö. (2017). An investigation on the implementation of project- based learning in elt, Republic of Turkey Çăg University Institute of Social Sciences Department of English Language Education.

Ayaz, M. F., \& Söylemez, M. (2015). Proje tabanlı öğrenmenin öğrencilerin fen derslerine yönelik tutumlarına etkisi: Bir meta-analiz çalışması. Adlyaman University Journal of Educational Sciences, 2016, 6(1), 112-137.

Aydın, S., Demir, A. T., \& Göksu, V. (2017). The effects of project based learning process on the academic self-efficacy and motivation of middle school students. Bartin University Journal of Faculty of Education, 6(2), 676-688.

Baran, M., \& Maskan, A. K. (2009). The effect of project-based learning approach on the second year's pre-service physics teachers' atitudes towards electrostatics. Dicle University Journal of Education Faculty, 12, 41-52.

Baş, G. (2011). Investigating the effects of project-based learning on students' academic achievement and attitudes towards English lesson. TOJNED: The Online Journal Of New Horizons In Education - October 2011, 1(4), 1-15.

Baş, G., \& Beyhan, Ö. (2010). Effects of multiple intelligences supported project-based learning on students' achievement levels and attitudes towards English lesson. International Electronic Journal of Elementary Education, $2(3)$.

Bayram, H., \& Seloni, Ş. R. (2014). Effect of project-based learning approach on 5th grade students' achievement attitude and conceptual understanding. Journal of Educational Sciences, 39, 71-84. https://doi.org/10.15285/EBD.2014397398

Beneke, S., \& Ostrosky, M. M. (2008). Teachers' views of the efficacy of incorporating the project approach into classroom practice with diverse learners. Young Children, (1), 1-9.

Brown, H. D. (2000). Principles of language learning and teaching (4th Ed.). London: Longman. Pearson Education limited.

Burstall, C. (1975). Factors affecting foreign-language learning: a consideration of some relevant research findings. Language Teaching and Linguistics Abstracts, 8, 5-125. https://doi.org/10.1017/S0261444800002585

Çıbık, A. S. (2009). The effect of the project- based learning approach to the attitudes of students towards science lesson, Elementary Education Online, 8(1), 36-47.

Çiftci, S. (2006). Sosyal Bilgiler Öğretiminde Proje Tabanlı Ögrenmenin Öğrencilerin Akademik Risk Alma Düzeylerine, Problem Çözme Becerilerine, Erisilerine, Kalıcılığa ve Tutumlarına Etkisi. Unpublished PhD Dissertation. Selcuk Universitesi Sosyal Bilimler Enstitüsü, Konya.

Çırak, D. (2006). The use of project- based learning in teaching English to young learners. Selçuk Üniversitesi Sosyal Bilimler Enstitüsü, Konya. 
Cömert, G. G. (2014) The Effect of Project Based Learning Oriented Instruction on Students Understanding of Human Circulatory System Concepts and Attitude Toward Biology. Yayımlanmamış Doktora Tezi. Orta Doğu Teknik Üniversitesi Fen Bilimleri Enstitüsü. Ankara.

Coşkun, M. (2004). Coğrafya Öğretiminde Proje Tabanlı Öğrenme Yaklaşımı. Yayınlanmamış Doktora Tezi, Gazi Üniversitesi, Ankara.

Demirel, Ö. (2013). Eğitimde program geliştirme kuramdan uygulamaya. Ankara: Pegem A Yayıncılık.

Demirel, Ö., Başbay, A., Uyangör, N., \& Biyikli, C. (2000). Proje tabanli öğrenme modelinin öğrenme surecine ve öğrenci tutumlarına etkisi. IX. Egitim Bilimleri Kongresi Bildirileri. Abant Izzet Baysal Universitesi Egitim Fakultesi, Bolu.

Dilşeker, Z. (2008). Fen ve teknoloji dersinde proje tabanlı öğrenme yöntemi kullanımının ilköğretim 5. Sınıf öğrencilerinin fen ve teknoloji dersine yönelik tutumlarına, ders başarısına ve kavram yanılgılarının giderilmesine etkisi. Yüksek LisansTezi, Dokuz Üniversitesi, İzmir.

English, M. C., \& Kitsantas, A. (2013). Supporting Student Self-Regulated Learning in Problem- and Project-Based Learning. Interdisciplinary Journal of Problem-Based Learning, 7(2). https://doi.org/10.7771/1541-5015.1339

Erdem, M. (2002). Projetabanlıöğrenme. HacettepeÜniversitesiEğitimFakültesiDergisi, 22, 172-179.

Erdem, M., \& Akkoyunlu, B. (2002). İlköğretim sosyal bilgiler dersi kapsamında beşinci sınıf öğrencileriyle yürütülen ekiple proje tabanlı öğrenme üzerine bir çalışma, Illköğretim-Online, 1(1), 2-11.

Faris, A. (2008). The impact of project-based learning on the students' attitudes towards science among nine graders in Hamza independent school. Analysis, 1-8.

Gardner, R. (1985). Social psychology and second language learning. The role of attitudes and motivation. London: Edward Arnold.

Gardner, R., \&Lambert, W. (1972). Attitudes and motivation in second language learning. Rowley, MA: Newbury House.

Gömleksiz, M. N., \& Fidan, E. K. (2013). Proje tabanlı öğrenme yönteminin web tasarımı dersinde kullanılmasına ilişkin nitel bir çalışma. Mersin University Journal of the Faculty of Education, 9(1), 120-135.

Gultekin, M. (2005). The effects of project-based learning on learning outcomes in the 5th grade social studies course in primary education. Educational Sciences: Theory and Practice, 5(2), 548-556.

Güven, B., \& Uzman, E. (2006). A study to develope a scale for measuring attitudes toward high school geography course. Kastamonu Education Journal, 14(2), 527-236.

Hedge, T. (1993). Key concepts in ELT. ELT Journal, 47(3), 275-277. https://doi.org/10.1093/elt/47.3.275

Hilton-Jones, U. (1988). Project-based learning for foreign students in an English-speaking environment. The 22nd International Conference of INIEFUTSSOL, 11-14 April,1988, University of Edinburgh, Scotland.

Holm, M. (2011). A review of the literature on effectiveness in prekindergarten through 12th grade classrooms. RivierAcademıc Journal, 7(2).

İnceoğlu, M. (2011). Tutum algı iletişim (6. Baskı). Ankara: Siyasal Kitabevi.

Karaçallı, S. (2011). İlköğretim 4. sınıf fen ve teknoloji dersinde proje tabanlı öğrenme yönteminin akademik başarıya, tutuma ve kalıcılığa etkisi. Yüksek Lisans Tezi, Mehmet Akif Ersoy Üniversitesi, Burdur.

Karasar, N. (2006). Bilimsel Araştırma Yöntemi. Ankara: Nobel Yayın Dağıtım.

Kırkız, Y. A. (2010). Öğrencilerin İngilizce dersine ait tutumları ile akademik başarıları arasındaki ilişki. Yayımlanmamış Yüksek Lisans Tezi, Trakya Üniversitesi. SosyalBilimlerEnstitüsü, Edirne.

Koparan, T., \& Güven, B. (2014). The effect of project based learning approach on students' statistical literacy levels towards probability. Journal of Research in Education and Teaching, 3(1), 60-84.

Korkmaz, H., \& Kaptan, F. (2001). Project-Based Learning Aproach in Science Education. Hacettepe Üniversitesi Ĕ̈itim Fakültesi Dergisi, 20, 193-200.

Köroğlu, M. Ö. (2011). İngilizce öğretiminde proje tabanlı öğrenme ve portfolio değerlendirme uygulamalarının lise öğrencilerinin başarısına etkisi. Uludağ Üniversitesi Eğitim Bilimleri Enstitüsü Eğitim Bilimleri Anabilim Dalı.

Legutke, M., \& Thomas, H. (1991). Process and experience in the language classroom. London: Longman.

McCarthy, T. (2010). Integrating project-based learning into a traditional skills-based curriculum to foster learner 
autonomy: An action research. The Journal of Kanda University of International Studies, 22.

Ozdemir, E. (2006). An investigation on the effects of project-based learning on students' achievement in and attitude towards geometry. Unpublished Master's Thesis. Middle East Technical University Graduate School of Natural and Applied Sciences, Ankara.

Rasul M. G., \& Hassan N. M. S. (2011). An innovative delivery and assessment of thermofluid engineering: a PBL course in undergraduate engineering program. Proceedings of the 2011 AAEE Conference, Fremantle, Western Australia.

Tonbuloğlu, B., Aslan, D., Sertel, A. S., \& Aydın, H. (2013). An effect of the project based learning on metacognitive skills, self-efficacy and established product quality. Mustafa Kemal University Journal of Social Sciences Institute, 10(23), 97-117.

Yaman, İ. (2014). EFL students attitudes towards the development of speaking skills via project- based learning: an omnipresent learning perspective. Yayımlanmamış Doktora Tezi. Gazi Üniversitesi, Eğitim Bilimleri Enstitüsü, Ankara.

Yılmaz, O. (2006). İlköğretim 7. Sınıf sosyal bilgiler dersinde “proje tabanlı öğrenme”nin öğrenenlerin akademik başarıları, yaratıcılıkları ve tutumlarına etkisi. YayınlanmamışYüksek Lisans Tezi. Zonguldak: Zonguldak KaraelmasÜniversitesi, SosyalBilimlerEnstitüsü.

Yiying, Z. (2015). Project-based learning in chinese college English listening and speaking course: from theory to practice. Canadian Social Science, 11(9), 40-44. https://doi.org/10.3968/7532

Yurtluk, M. (2003). Projetabanlı̈̆ğrenmeyaklaşımınınmatematikdersiöğrenmesüreciveöğrencitutumlarınaetkisi. Yayımlanmamış Yüksek LisansTezi. Hacettepe Üniversitesi Sosyal Bilimler Enstitüsü, Ankara.

Yurttepe, S. (2007). İlköğretim fen bilgisi dersinde proje tabanlı öğrenmenin öğrenci başarısına etkisi. Yayımlanmamış Yüksek Lisans Tezi, Osmangazi Üniversitesi, Fen Bilimleri Enstitüsü, Eskişehir.

\section{Copyrights}

Copyright for this article is retained by the author(s), with first publication rights granted to the journal.

This is an open-access article distributed under the terms and conditions of the Creative Commons Attribution license which permits unrestricted use, distribution, and reproduction in any medium, provided the original work is properly cited. 